\title{
Harlequin duck population recovery following the ‘Exxon Valdez' oil spill: progress, process and constraints
}

\author{
Daniel Esler ${ }^{1, *}$, Timothy D. Bowman ${ }^{2}$, Kimberly A. Trust $^{3}{ }^{3}$ Brenda E. Ballachey ${ }^{1}$, \\ Thomas A. Dean ${ }^{4}$, Stephen C. Jewett ${ }^{5}$, Charles E. O'Clair ${ }^{6}$ \\ ${ }^{1}$ US Geological Survey, Alaska Biological Science Center and ${ }^{2}$ US Fish and Wildlife Service, 1011 East Tudor Road, \\ Anchorage, Alaska 99503, USA \\ ${ }^{3}$ US Fish and Wildlife Service, 605 West 4th Avenue, Room G62, Anchorage, Alaska 99501, USA \\ ${ }^{4}$ Coastal Resources Associates, Inc., 1185 Park Center Drive, Suite A, Vista, California 92083, USA \\ ${ }^{5}$ Institute of Marine Science, University of Alaska Fairbanks, Room 118, O`Neill Building, Fairbanks, Alaska 99775, USA \\ ${ }^{6}$ National Oceanographic and Atmospheric Administration, Auke Bay Laboratory, 11305 Glacier Highway, Juneau, \\ Alaska 99801, USA
}

\begin{abstract}
Following the 1989 'Exxon Valdez' oil spill in Prince William Sound, Alaska, we studied the status of recovery of harlequin duck Histrionicus histrionicus populations during 1995 to 1998 . We evaluated potential constraints on full recovery, including (1) exposure to residual oil; (2) food limitation; and (3) intrinsic demographic limitations on population growth rates. In this paper, we synthesize the findings from our work and incorporate information from other harlequin duck research and monitoring programs to provide a comprehensive evaluation of the response of this species to the 'Exxon Valdez' spill. We conclude that harlequin duck populations had not fully recovered by 1998. Furthermore, adverse effects continued as many as $9 \mathrm{yr}$ after the oil spill, in contrast to the conventional paradigm that oil spill effects on bird populations are short-lived. These conclusions are based on the findings that (1) elevated cytochrome P450 (CYP1A) induction on oiled areas indicated continued exposure to oil in 1998; (2) adult female winter survival was lower on oiled than unoiled areas during 1995 to 1998; (3) fall population surveys by the Alaska Department of Fish and Game indicated numerical declines in oiled areas during 1995 to 1997; and (4) densities on oiled areas in 1996 and 1997 were lower than expected using models that accounted for effects of habitat attributes. Based on hypothesized links between oil contamination and demography, we suggest that harlequin duck population recovery was constrained primarily by continued oil exposure. Full population recovery will also be delayed by the time necessary for intrinsic population growth to allow return to pre-spill numbers following cessation of residual oil spill effects. Although not all wildlife species were affected by the 'Exxon Valdez' oil spill, and some others may have recovered quickly from any effects, harlequin duck life history characteristics and benthic, nearshore feeding habits make them susceptible to both initial and long-term oil spill effects.
\end{abstract}

KEY WORDS: Demography · 'Exxon Valdez' • Harlequin duck · Histrionicus histrionicus • Marine birds - Oil contamination · Population recovery

\section{INTRODUCTION}

Harlequin ducks Histrionicus histrionicus spend most of the year in nearshore marine habitats (Robert- son \& Goudie 1999), where they feed on benthic invertebrates (Goudie \& Ankney 1986) in intertidal and shallow subtidal zones. Aspects of harlequin duck ecology make their populations particularly suscepti- 
ble to perturbations of their wintering environment. Harlequin ducks, like many sea ducks, have a life history in which variable and generally low annual productivity is compensated by relatively high adult survival and long reproductive life spans (Goudie et al. 1994). This type of strategy evolves under conditions of predictable and stable nonbreeding environments, which are required to ensure adult survival (Stearns 1992). Also, harlequin ducks, because of their small body size, are thought to exist near an energetic threshold during winter, with little flexibility for increasing caloric intake or relying on stored reserves (Goudie \& Ankney 1986). While this strategy may be tenable under predictable and stable conditions, it does not readily accommodate perturbations that result in either decreases in energy acquisition or increases in metabolic costs. Finally, strong site fidelity, such as that exhibited by wintering harlequin ducks, evolves in predictable and stable habitats (Johnson \& Gaines 1990, Robertson \& Cooke 1999, Cooke et al. 2000) and does not facilitate movement to undisturbed areas if local habitat quality becomes degraded (Hilden 1965, Cooch et al. 1993).

The release of approximately 42 million 1 of crude oil into Prince William Sound (PWS) by the 1989 'Exxon Valdez' oil spill (EVOS) was a significant perturbation to harlequin duck nonbreeding habitat. As much as $40 \%$ of the spilled oil was deposited in intertidal and subtidal zones of PWS (Galt et al. 1991, Wolfe et al. 1994) and oil persisted in these areas more than $8 \mathrm{yr}$ after the oil was spilled (Hayes \& Michel 1999). Vulnerability of harlequin ducks to oil spill effects is exacerbated by their diet of intertidal and shallow subtidal benthic invertebrates (Vermeer 1983, Goudie \& Ankney 1986, Gaines \& Fitzner 1987, Goudie \& Ryan 1991, Patten et al. 2000) as oil constituents can accumulate in bottom sediments and subsequently, in benthic invertebrates (Fukuyama et al. 2000, Peterson 2001). Petroleum hydrocarbons occurred in harlequin duck prey from immediately after the spill through at least 1995 (Boehm et al. 1995, Babcock et al. 1996, Short \& Babcock 1996, Wolfe et al. 1996, Patten et al. 2000).

In this paper, we examine effects of the EVOS on harlequin duck populations in PWS and consider potential constraints on full population recovery. The first objective is to review data that provide insight into population injury and recovery status. The second objective is to evaluate mechanisms potentially constraining full recovery, including (1) intrinsic demographic limitations on population growth rates that delay return to prespill numbers despite lack of continuing oil spill effects; (2) health effects of continued oil exposure at levels that have population consequences; and (3) food limitation due to oil spill-related reduc- tions in prey that either lowers carrying capacity or reduces health and survival of individual ducks.

Data used in this synthesis were gathered from journal publications and Exxon Valdez Oil Spill Trustee Council reports, both from our own studies conducted during 1995 to 1998 and from other research and monitoring programs in PWS after the spill. We also reviewed published studies of harlequin duck ecology conducted throughout their range and their implications for understanding constraints on full recovery from the EVOS.

PWS is prime nonbreeding habitat for harlequin ducks. It supports about 14000 birds during winter (Lance et al. 1999), although it is one of the northernmost wintering areas within the species' range (Robertson \& Goudie 1999). Some reproduction occurs in streams feeding into PWS (Crowley 1999), but most harlequin ducks that winter in PWS nest outside of the area. Breeding locations have not been determined and could extend throughout the vast breeding range in Alaska and the Yukon Territories (Robertson \& Goudie 1999).

\section{INJURY AND RECOVERY STATUS}

We reviewed studies conducted after the EVOS that lend insight into harlequin duck population injury and recovery. We categorized these as studies of population status, adult female survival and body mass variation.

\section{Population status}

Several studies are relevant for evaluating harlequin duck population status, most of which were conducted outside of our own research program. These measured a range of population parameters, including direct mortalities, abundance, numerical trends, densities, age and sex ratios, and habitat use. Generally, we would predict that these population parameters (excluding initial mortalities) would be similar in oiled and unoiled areas once full population recovery had occurred. However, this prediction rests on a suite of assumptions and is subject to a number of problems (Wiens \& Parker 1995). For example, lack of comprehensive prespill data for many parameters (e.g. winter densities, habitat use, age and sex ratios) precluded use of a before-after-control-impact (BACI) design, which can be used to distinguish effects of an environmental perturbation from natural spatial and temporal variation. Also, comparisons between affected and control areas, without preperturbation data, often assume that natural attributes of the areas are similar 
(Wiens \& Parker 1995); for harlequin duck population parameters, sometimes that assumption could be addressed, but not always. Finally, changes in demographic endpoints such as numbers, trends or densities do not address underlying demographic processes and thus can not indicate mechanisms leading to population change. However, despite these limitations and assumptions, convergence of population densities, trends, and age and sex distributions in oiled and unoiled areas would be consistent with population recovery.

Estimates of direct mortality of birds due to the EVOS were based on recovery of carcasses (Piatt et al. 1990), expanded to account for the proportions of dead birds that were not recovered (Piatt \& Ford 1996). The true fraction of all dead birds retrieved after the EVOS is difficult to determine, even with data from experimental carcass drift and recovery studies (Piatt \& Ford 1996). The associated uncertainty has led to controversy about the numbers of birds killed by acute effects of the EVOS (Parrish \& Boersma 1995, Piatt \& Ford 1996), although Piatt \& Ford (1996) convincingly argue that despite uncertainty, incorporation of estimated recovery rates is appropriate and realistic. In the case of the EVOS, even when using a variety of recovery rates, estimates of the magnitude of total bird mortality were similar (Piatt \& Ford 1996). Immediately following the EVOS, 212 harlequin duck carcasses were recovered, including 147 in PWS; using a recovery rate of $15 \%$ (Piatt \& Ford 1996), the estimate of total harlequin mortality due to immediate effects of the EVOS was 1413, with 980 of those in PWS (J. Piatt pers. comm.). This mortality estimate represents roughly $7 \%$ of the harlequin ducks wintering throughout PWS, and a much higher proportion of those wintering in oiled areas of PWS. Sea ducks were quite vulnerable to immediate effects of the oil spill; numbers of oiled sea duck carcasses recovered in PWS exceeded those of any other taxa (Piatt et al. 1990). Mortality estimates from carcasses retrieved just after the spill indicate immediate population injury, but do not address any subsequent, longer-term effects of the EVOS.

Patten et al. (2000) conducted damage assessment studies immediately following the EVOS, focusing on contaminant exposure and abundance. They found hydrocarbon metabolites in $74 \%$ of live harlequin ducks collected from oiled areas in 1989 and 1990, consistent with exposure to oil and implying potential for injurious effects. Also, numbers of adults and broods were lower in oiled areas of PWS than in unoiled areas (Patten et al. 2000); however, this study did not account for potential geographic variation from natural causes, which may contribute to or explain observed differences. For example, lower numbers of broods in oiled areas do not necessarily indicate that harlequin pro- ductivity was affected by the EVOS because (1) most of the wintering population migrates outside of PWS to breed; (2) within PWS, breeding habitats used by harlequin ducks (Crowley 1994) are found primarily in eastern, unoiled areas (Rosenberg \& Petrula 1998); and (3) prespill records of broods in oiled areas could have been flightless birds during wing molt that were misclassified (Rosenberg \& Petrula 1998). However, no data have been collected to explicitly examine reproductive effort of harlequin duck subpopulations from oiled areas, so we cannot eliminate the possibility that the EVOS had deleterious effects on harlequin duck reproduction.

The US Fish and Wildlife Service has conducted marine bird surveys during summer (July) and winter (March) in PWS since 1989 (Lance et al. 1999). While these were not explicitly designed to estimate harlequin duck numbers or population trends, they do provide a long-term assessment of population status. Prespill survey data exist for PWS from summers 1984 and 1985, which have been used for comparison to postspill data (Irons et al. 2000). Unfortunately, prespill survey data for PWS in winter, the period of high and stable harlequin duck numbers, are not adequate for before-after comparisons, although postspill data can be used to compare winter trends between oiled and unoiled areas (Lance et al. 2001). Also, from 1995 to 1997, the Alaska Department of Fish and Game conducted surveys designed specifically to assess harlequin duck population status (Rosenberg \& Petrula 1998). They surveyed during spring (May and June) and fall (late July to September) and measured numbers, pair status (paired versus unpaired), sex ratios, age composition and molt chronology in oiled and unoiled areas (over more than $250 \mathrm{~km}$ shoreline in each area). These surveys have more statistical power for estimating abundance and trends than US Fish and Wildlife Service surveys (Rosenberg \& Petrula 1998), and their fall data provide the best estimates of population trends for nonbreeding populations during the course of our research (1995 to 1998).

Using a BACI design, Irons et al. (2000) found that harlequin duck densities were lower than expected in oiled areas of PWS during the summers of 1990 and 1991, based on comparison to observed changes in reference areas. This effect was not evident in subsequent years. Lance et al. (2001) reported stable densities of harlequin ducks in oiled areas of PWS during summer, and increasing densities during winter from 1989 through 1998; the increasing trend during winter could be interpreted as evidence of recovery of winter numbers. However, trends in oiled areas did not differ from those in unoiled areas (during summer or winter). Lance et al. (1999) interpreted this result as evidence of lack of recovery, under the premise that an EVOS-injured population 
should have a higher growth rate than reference populations for convergence and thus recovery to be occurring. Alaska Department of Fish and Game surveys (Rosenberg \& Petrula 1998) indicated that fall numbers significantly declined on oiled areas from 1995 through 1997, whereas numbers were stable on unoiled areas, consistent with a hypothesis that continued, negative effects of the EVOS were occurring during the time of their survey. Measures of other population attributes (age ratios, sex ratios and phenology) did not differ between oiled and unoiled areas (Rosenberg \& Petrula 1998). Results of the US Fish and Wildlife Service and Alaska Department of Fish and Game support the general conclusions that harlequin duck populations were reduced in the years immediately after the spill, that populations were not increasing more quickly in oiled areas through at least 1998, and that the most powerful monitoring study indicated declines in wintering numbers in oiled areas through 1997, consistent with continuing negative effects of the EVOS.

Exxon Corporation sponsored studies to assess effects of the EVOS on marine birds (Wiens et al. 1996, Day et al. 1997, Murphy et al. 1997). These studies relied on data collected following the EVOS (1989 through 1991) in 10 bays in western PWS across a range of oil contamination levels. While designed to examine all marine birds, these studies also drew conclusions relevant to assessment of harlequin duck population status. Authors of these studies concluded that oil spill effects were short-lived for most bird species based on their response parameters of species richness (Wiens et al. 1996), habitat use (Day et al. 1997) and

Table 1. Histrionicus histrionicus. Results of general linear model analyses to evaluate relationships of harlequin duck densities (square-root transformed) in Prince William Sound, Alaska, during winters 1995 to 1997, with habitat attributes and history of oil contamination by the 1989 'Exxon Valdez' oil spill. The parameter estimates $( \pm \mathrm{SE})$ are from the best-fitting model, based on comparisons of all possible combinations of habitat attribute variables, habitat by area interactions and an area (history of oil contamination) term. From Esler et al. (2000a)

\begin{tabular}{|c|c|c|}
\hline $\begin{array}{l}\text { Response variable } \\
\quad \mathrm{R}^{2}\end{array}$ & $\begin{array}{l}\text { Explanatory } \\
\text { variable }\end{array}$ & $\begin{array}{l}\text { Parameter } \\
\text { estimate }\end{array}$ \\
\hline \multicolumn{3}{|l|}{ Ducks per $400 \mathrm{~m}$} \\
\hline 0.45 & Intercept & $1.17 \pm 0.12$ \\
\hline & Reef $200-500 \mathrm{~m}^{\mathrm{a}}$ & $0.51 \pm 0.15$ \\
\hline & Stream $0-200 \mathrm{~m}^{\mathrm{a}}$ & $0.34 \pm 0.14$ \\
\hline & Full exposure to wind/waves ${ }^{a}$ & $0.45 \pm 0.12$ \\
\hline & Mixed substrate ${ }^{a}$ & $0.32 \pm 0.14$ \\
\hline & Mixed substrate $\times$ Area $^{\mathrm{b}}$ & $-0.48 \pm 0.18$ \\
\hline & Area $^{\mathrm{b}}$ & $-0.69 \pm 0.12$ \\
\hline
\end{tabular}

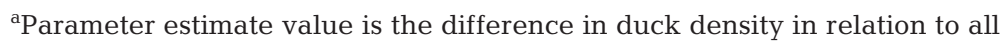
other levels of the explanatory variable

${ }^{\mathrm{b}}$ Reference value for area is unoiled Montague Island; parameter estimates are interpreted as effects on oiled Knight Island summer abundance relative to prespill data (Murphy et al. 1997). In the studies that present results for harlequin ducks explicitly, Day et al. (1997) concluded that harlequin duck densities showed negative relationships with oiling intensity during 1989 and 1990, but not in 1991, and Murphy et al. (1997) concluded that summer abundance in western PWS did not differ from prespill numbers. Generally, these studies imply intial population injury and recovery within $2 \mathrm{yr}$; these are contrasted with US Fish and Wildlife and 'Discussion'.

As part of our research, we examined correlates of harlequin duck densities within oiled (Bay of Isles and Bay on Knight Island) and unoiled (Montague va study areas (Fig. 1). We formally evaluated acteristics including substrate, exposure to wind and waves, distance to stream mouths and offshore reefs, intertidal slope, prey biomass and history of contamination by the EVOS (Esler et al. 2000a). Habitats in PWS are diverse, making it necessary to segrete effects of oil contamination from other naturally ing environmental factors (Wiens \& Parker 1995). (after accour tensities than expected on oiled area either failure of the population to recover from the immediate impact or from ongoing, longer-term negative effects of the EVOS; in either case, this result would be consistent with a lack of full population recovery. During 1995 to 1997, we surveyed densities of wintering harlequin ducks and measured habitat attributes at 216 shoreline segments (113 on oiled Knight Island and 103 on unoiled Montague Island; Fig. 1). We used general linear models to evaluate variation in harlequin duck densities in relation to habitat attributes and history of oiling, using informationtheoretic methods for model selection (Burnham \& Anderson 1998). We found (Esler et al. 2000a) that harlequin duck densities during winter were related to several habitat attributes, including substrate type, distance to offshore reefs, distance to stream mouths, and exposure to wind and wave action (Table 1). After accounting for these habitat relationships and their interactions with area, oiling history was negatively related to harlequin duck densities (Table 1). These data are consistent with a hypothesis of lack of complete population recovery from the EVOS. 


\section{Adult female survival during winter}

Within our research program, we used radio telemetry to measure adult female survival during winter (Esler et al. 2000b), because (1) population dynamics of species with a life history like harlequin ducks are particularly sensitive to adult female survival (Goudie et al. 1994, Schmutz et al. 1997); and (2), as described above, harlequin duck populations are sensitive to perturbations on wintering areas, which could result in reductions in survival. As an assessment of recovery status, we would predict similar harlequin duck winter survival between oiled and unoiled areas in the absence of continuing EVOS effects. We also would predict survival rates that result in stable or increasing numbers on oiled areas if there were no lingering effects of the EVOS.

During autumns of 1995 through 1997, we captured adult females during wing molt throughout the oil spill zone and on nearby Montague Island (Fig. 1) and surgically implanted conventional radio transmitters. Radio signals ( $\mathrm{n}=294$ over the 3 winters) were monitored by air approximately weekly from October through March.

We used an information-theoretic approach for data analysis (Burnham \& Anderson 1998, White \& Burnham 1999), in which we contrasted the fit of our data to 11 models with various combinations of season and area (history of oil contamination) parameters.

The data strongly supported the inference that survival was lower in oiled areas than unoiled areas (Esler et al. 2000b). The top 3 models, i.e. those with the best fit to the data, all included a difference in survival between areas. Further, models without an area term had very little support, emphasizing the importance of including a term for an area effect. Winter survival rates from the best-fitting model were $78.0 \%$ (SE = $3.3 \%)$ on oiled areas and $83.7 \%(\mathrm{SE}=2.9 \%)$ on unoiled areas, due primarily to a divergence between areas during mid-winter (Fig. 2). We also determined that survival differences between oiled and unoiled areas were more likely related to the history of oil contamination than intrinsic differences (such as habitat, disease, climate, social influences or predator densities); this was based on a closer evaluation of survival rates of birds from oiled Green Island, which is very close to Montague Island (Fig. 1) and is similar in most attributes. Survival of Green Island birds was much more similar to that of all oiled area birds combined than to Montague Island birds. Finally, we incorporated survival estimates into a pre-existing harlequin duck population model (Robertson 1997), holding all other parameters constant, to evaluate the effect of differences in survival on population dynamics. The estimate of annual population change $(\lambda)$ was 0.9464 for oiled areas (i.e. annual population declines of about $5.4 \%$ ). For unoiled areas, $\lambda=1.0054$, suggesting an approximately stable population. These estimates were consistent with the Alaska Department of Fish and Game (Rosenberg \& Petrula 1998) fall survey results, showing declining numbers from 1995 to 1997 on oiled areas and stable numbers on unoiled areas.

\section{Variation in body mass and composition}

Body mass and body composition (relative amounts of lipid and lean mass) are often used as indicators of individual and population health under the assumption that fitness increases with increases in mass and 


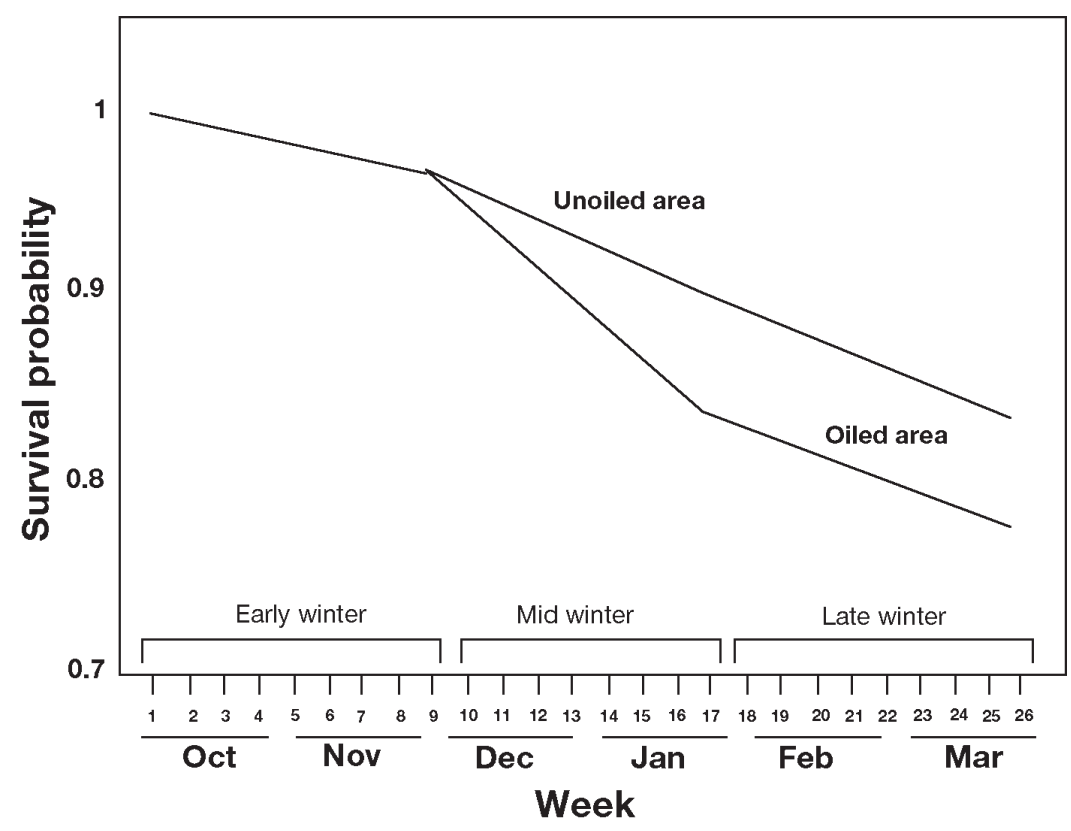

Fig. 2. Histrionicus histrionicus. Winter survival probabilities for adult females in Prince William Sound, Alaska based on radio telemetry data combined over winters 1995-1996 through 1997-1998 (Esler et al. 2000b) thus presumably similar body mass optima), differences in body mass between areas could reflect continuing effects of the EVOS. Thus, we would predict that EVOS effects related to changes in prey abundance or sublethal effects of oil exposure could result in lower body mass and smaller lipid reserves on oiled areas than unoiled.

We compared body mass between oiled and unoiled areas during wing molt (late summer and early fall) 1995 to 1997 and winter $1997-1998$ as part of our research program, using general linear models to determine factors explaining variation in harlequin duck body mass and to evaluate any area differences after accounting for other explanatory variables. We used separate models for wing molt and winter and, within each season, separate models for each sex. To select the model from which we drew inference, we used Mallow's $C_{p}$ values to contrast all possible combinations of explanatory energy reserves. This assumption is most likely to be untrue in a number of situations (King \& Murphy 1985), i.e. optimal body mass may not be the maximum, particularly for birds. However, in our situation, in which we were comparing populations of harlequin ducks experiencing similar extrinsic environmental conditions with the exception of oiling history (and

Table 2. Histrionicus histrionicus. Effect sizes $(g \pm \mathrm{SE})$ of body mass and composition comparisons between oiled and unoiled areas of Prince William Sound, Alaska. These are parameter estimates for an area term from multiple regression analyses and represent differences in body mass or composition between areas after accounting for the other explanatory variables in the bestfitting model. The reference value for the area term was unoiled areas and hence, the parameter estimates represent the difference in body mass or composition on oiled areas

\begin{tabular}{|c|c|c|}
\hline \multirow{2}{*}{$\begin{array}{l}\text { Sex } \\
\text { Response variable }\end{array}$} & \multicolumn{2}{|c|}{ Season } \\
\hline & Wing molt & Winter \\
\hline \multicolumn{3}{|l|}{ Female } \\
\hline Body mass & $-9.6( \pm 2.6)$ & $0.00( \pm 0.0)^{\mathrm{a}}$ \\
\hline Lipid mass & $-2.5( \pm 0.7)$ & $-{ }^{\mathrm{b}}$ \\
\hline Lean mass & $-7.0( \pm 2.0)$ & $-{ }^{\mathrm{b}}$ \\
\hline \multicolumn{3}{|l|}{ Male } \\
\hline Body mass & $13.4( \pm 4.5)$ & $-21.5( \pm 8.7)$ \\
\hline $\begin{array}{l}\text { a The area term was } \mathrm{r} \\
{ }^{\mathrm{b}} \text { Lipid and lean mass } \\
\text { ing winter }\end{array}$ & $\begin{array}{l}\text { ncluded in th } \\
\text { re not estima }\end{array}$ & $\begin{array}{l}\text { fitting model } \\
\text { females dur- }\end{array}$ \\
\hline
\end{tabular}

variables (Burnham \& Anderson 1998). Explanatory variables in wing molt models included year, age, 9th primary length (as a measure of stage of molt) and area. For winter, explanatory variables included age, season (December vs March and April) and area. We also compared estimated lipid and lean (lipid-free) masses of female harlequin ducks captured during wing molt based on condition indices created from a sample of collected harlequin duck females collected during wing molt for which composition was measured using laboratory analysis.

During wing molt, variation in female harlequin duck body mass was related to stage of wing molt, age and year. After accounting for effects of these variables, females averaged $9.6 \mathrm{~g}$ lighter on oiled areas than unoiled (Table 2). This represents $1.6 \%$ of average body mass of molting females on unoiled Montague Island. Similarly, estimated body lipid and lean averaged 2.5 and $7.0 \mathrm{~g}$ lower, respectively, in oiled areas than in unoiled areas. Like females, male body mass was related to stage of wing molt. After accounting for molt stage, average body mass differed by area, although unlike females, male body mass averaged $13.4 \mathrm{~g}$ higher in oiled areas than unoiled, a $2.0 \%$ increase over average body mass on unoiled areas.

During winter, female body mass varied with season (mid- vs late winter) and age; however, no area effect was detected (Table 2). Body mass of males also varied seasonally during winter and averaged $21.6 \mathrm{~g}$ lower in 
oiled areas than unoiled areas, which corresponds to $3.3 \%$ of average body mass on unoiled areas.

Most of the body mass and composition data were consistent with a hypothesis of no continuing effects of the EVOS. Area differences during wing molt were small and were in different directions for males and females; the high statistical power due to the large sample size of captured birds allowed statistically significant detection of small differences of little biological meaning. The $21.6 \mathrm{~g}$ body mass difference between areas for male harlequin ducks during winter suggests potential residual EVOS effects; however, because the effect is relatively small and because females captured during the same time on the same areas did not show a similar effect, this does not constitute strong evidence of an EVOS effect.

We also tested whether body mass of wintering harlequin ducks was related to induction of cytochrome P4501A (CYP1A) (Trust et al. 1998), an indicator of exposure to oil (see 'Continued exposure to oil'). For birds captured during March and April 1998 on both oiled and unoiled areas, we used a regression approach to measure the effect of CYP1A on body mass after accounting for body mass variation due to sex. We found that sex-corrected body mass was negatively related $\left(-0.11 \pm 0.05 ; \mathrm{g} \mathrm{pmol}^{-1} \mathrm{~min}^{-1} \mathrm{mg}^{-1} \pm \mathrm{SE}\right)$ to 7 -ethoxyresorufin-O-deethylase (EROD) activity (Fig. 3). These data suggest physiological consequences of oil exposure, with potential demographic consequences. Survival of some wintering ducks has been demonstrated to vary with body mass (Conroy et al. 1989, Longcore et al. 1991, Bergan \& Smith 1993), indicating a mechanism linking contaminant exposure and reductions in survival.

\section{Intrinsic limitations on population growth rates}

Full recovery of harlequin duck populations could be delayed by the time needed for intrinsic population growth to replace birds removed by initial or early oil spill effects. In other words, even if negative effects related to the EVOS (mortality and emigration) had ended, the time required for demographic effects (recruitment and immigration) to rebuild populations to prespill conditions could be considered a constraint on full recovery. In this section, we review data on harlequin duck demography and population structure that lend insight into this possible mechanism constraining recovery.

Population models, based on demographic data collected from throughout the range of the harlequin duck (Goudie et al. 1994, Robertson 1997), provide an indication of population growth potential. Goudie et al. (1994) concluded that the potential growth rate of

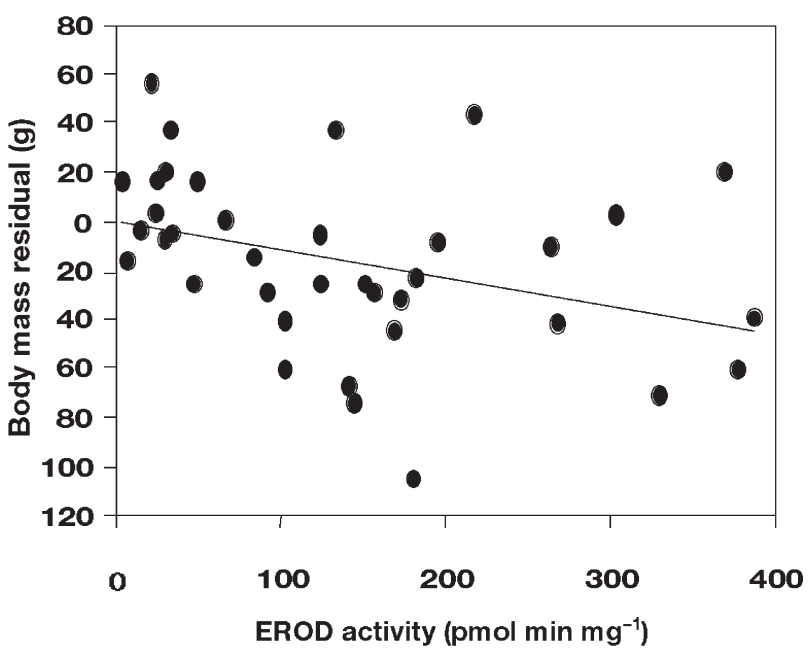

Fig. 3. Histrionicus histrionicus. Relationship of body mass residuals (i.e. accounting for mass differences between sexes) with CYP1A induction, as measured by liver 7-ethoxyresorufin-O-deethylase (EROD) activity, an indicator of exposure to polycyclic aromatic hydrocarbons (PAHs)

harlequin duck populations is low relative to most other ducks because of their life history strategy favoring high survival and long lifespans over high annual productivity. Other waterfowl with similar life histories also have low population growth rates (Schmutz et al. 1997). These data suggest that full recovery of harlequin duck populations could be delayed by the relatively long time frames needed for recruitment to replace birds removed as a result of EVOS effects, even if those effects were no longer operating.

Local wintering aggregations could constitute demographically independent subpopulations if site fidelity is high and dispersal among areas low (Cooke et al. 2000). We reviewed published studies addressing harlequin duck site fidelity and movements in coastal British Columbia; these studies consistently indicated high molt and winter site fidelity and low dispersal (Breault \& Savard 1999, Robertson et al. 1999, 2000, Cooke et al. 2000). Also, Regehr et al. (2001) reported evidence that juvenile harlequin ducks accompany their mothers to wintering areas, which further indicates that local wintering groups represent aggregations that are largely independent.

We also examined data collected during our own studies to assess molt site fidelity based on recapture locations. We conducted captures of flightless (due to wing molt) birds along discrete, non-overlapping stretches of shoreline that were 1 to $3 \mathrm{~km}$ in length during falls of 1995 through 1997. These captures occurred throughout the oil spill zone and along Montague Island. For individuals that we captured in more 
than 1 year, we summarized recaptures in relation to the distance from the original capture. Of 151 harlequin ducks recaptured during wing molt, 135 (89.5\%) were in the same shoreline segment as their original capture, 10 (6.6\%) were in an immediately adjacent shoreline segment (i.e. a segment within $1 \mathrm{~km}$ of the original capture segment) and $6(4.0 \%)$ had moved to a molting area $>1 \mathrm{~km}$ from their original capture location. Also, of the birds recaptured at a different shoreline segment, none was $>20 \mathrm{~km}$ from its original capture location. Larger-scale movements may have occurred, but we would have detected them if they were common, given that we sampled broadly and intensively throughout western PWS. These data, and the results from other studies, indicate that groups of wintering harlequin ducks are largely demographically independent and that local subpopulation recovery would have to occur largely by recruitment rather than by immigration. Without positive inputs by immigration, local population recovery from the EVOS is more likely to be constrained.

Lanctot et al. (1999) used genetic data to evaluate whether harlequin duck aggregations within the EVOS zone were demographically isolated. DNA was obtained from blood samples of molting harlequin ducks from oiled and unoiled areas of PWS, the Kodiak Archipelago and the Alaska Peninsula, which are separated at the scale of $100 \mathrm{~s}$ of $\mathrm{km}$. With this approach, significant differences in nuclear DNA allele frequencies or mtDNA haplotype frequencies among areas would be strong evidence that aggregations are demographically independent (e.g. Slatkin 1995) and, thus, that intrinsic limitations on population growth rates

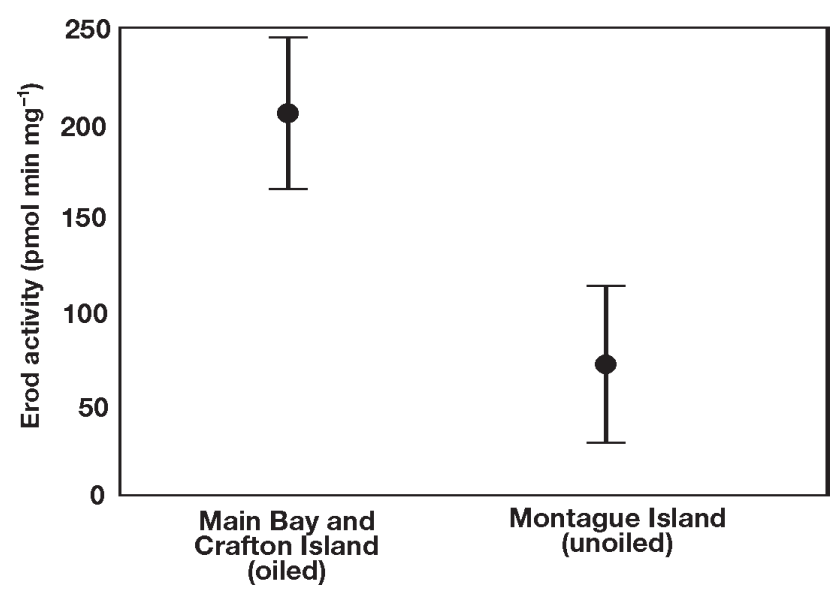

Fig. 4. Histrionicus histrionicus. Comparisons of average $( \pm 95 \%$ confidence intervals) liver 7-ethoxyresorufin-Odeethylase (EROD) activity, as a measure of CYP1A induction, of harlequin ducks captured from oiled and unoiled areas of Prince William Sound, Alaska in March and April 1998 (Trust et al. 2000) could constrain population recovery. However, Lanctot et al. (1999) found that molting aggregations in PWS, the Kodiak Archipelago and the Alaska Peninsula did not have different allele or haplotype frequencies. Lack of genetic differentiation does not necessarily imply demographic panmixia; genetic panmixia also could occur from historical gene flow or from low levels of immigration (Wright 1931) that have little effect on local demography.

\section{Continued exposure to oil}

Exposure to oil has been documented to have a suite of deleterious toxic (Leighton 1993) and energetic (Jenssen 1994) consequences for birds. To determine if harlequin ducks in PWS were still being exposed to residual oil, we (Trust et al. 2000) measured induction of CYP1A in harlequin ducks captured during March and April 1998 in both oiled and unoiled areas. CYP1A is induced upon exposure to polycyclic aromatic hydrocarbon (PAH) constituents of crude oil and has proven to be a sensitive and fairly specific indicator of oil exposure (e.g. Woodin et al. 1997). In addition to oil-derived PAHs, certain polychlorinated biphenyl (PCB) congeners can induce CYP1A systems (Rattner et al. 1994). Therefore, we also measured congener-specific PCB concentrations in plasma from harlequin ducks wintering in PWS to contrast with CYP1A enzyme activity. Evidence of exposure to oil would not necessarily imply that exposure had adverse physiological or demographic consequences. However, evidence of exposure would be consistent with potential for these deleterious consequences, and could be interpreted in light of other available data as a possible mechanism constraining full population recovery.

Liver EROD activity $( \pm \mathrm{SE})$ is an indicator of CYP1A induction. EROD activity in wintering harlequin ducks was higher in oiled areas (204.6 \pm 20.3 pmol $\min ^{-1} \mathrm{mg}$ protein ${ }^{-1}, \mathrm{n}=19$ ) than on unoiled Montague Island $\left(70.7 \pm 21.5 \mathrm{pmol} \mathrm{min}^{-1} \mathrm{mg}\right.$ protein $^{-1}, \mathrm{n}=$ 18, p $<0.001$; Fig. 4; Trust et al. 2000). This is strong evidence of continued exposure to 'Exxon Valdez' oil, given that background $\mathrm{PAH}$ concentrations in intertidal sediments and mussel tissues were negligible in PWS immediately prior to the EVOS (Short \& Babcock 1996). Area differences in CYP1A induction could not be explained by differences in PCB exposure (Trust et al. 2000); congener-specific PCB concentrations were low and did not differ between areas. These data suggest that continued oil exposure could be limiting population recovery if there were physiological and population consequences of this exposure. 


\section{Food limitation}

Food limitation could constrain population recovery if the EVOS resulted in reduction in abundance of harlequin duck prey. This could occur from either direct effects (e.g. acute toxicity or habitat destruction during cleanup activities) or indirect effects (e.g. changes in food web structure; Peterson 2001). In turn, prey reductions could lead to increased intraspecific competition or reduced health of individuals, either of which could have population-level consequences.

During winter, the diet of harlequin ducks consists of a broad array of benthic marine invertebrates, especially amphipods, limpets, other snails, chitons and mussels (Vermeer 1983, Goudie \& Ankney 1986, Gaines \& Fitzner 1987, Goudie \& Ryan 1991, Patten et al. 2000). Goudie \& Ankney (1986) hypothesized that harlequin ducks are trophic generalists because they must feed continuously to meet metabolic needs during winter; high energy prey (e.g. amphipods) are consumed when encountered, but lower quality prey are consumed when high energy prey are not available.

Effects of the EVOS on populations of several important harlequin duck prey were evaluated by sampling at multiple pairs of oiled and unoiled sites in intertidal and nearshore subtidal habitats shortly after the spill (Highsmith et al. 1996, Jewett et al. 1999). Numerically dominant taxa within several important harlequin duck prey groups (limpets, other snails, mussels and amphipods) were reduced in density by the oil spill. At oiled sites, numbers of Mytilus trossulus (mussels), Tectura persona (limpets) and Littorina sitkana (littorine snails), were reduced in the years following the EVOS (Highsmith et al. 1996). Similarly, several numerically dominant amphipod taxa were reduced at oiled sites in the nearshore subtidal zone (Jewett et al. 1999). Many of these differences in mean abundance at oiled and reference sites were no longer evident in 1993 (Hooten \& Highsmith 1996, Houghton et al. 1996), suggesting that recovery of the intertidal and nearshore subtidal community was well underway. However, the last reported values suggest that there continued to be fewer individuals of some important prey at selected oiled sites, at least through 1993 in the intertidal (Hooten \& Highsmith 1996, Houghton et al. 1996) and through 1995 in the subtidal (Jewett et al. 1999) sites. Reduced prey densities at oiled sites can be largely attributed to the direct toxic effects of oil and impacts associated with cleanup procedures (Boehm et al. 1995, Houghton et al. 1996, Wolfe et al. 1996, Jewett et al. 1999). These results are consistent with food limitation of harlequin duck population recovery, at least within the few years immediately following the EVOS.

We estimated availability of harlequin duck prey items (Esler et al. 2000a) on oiled Knight Island (Bay of
Isles and Herring Bay) and unoiled Montague Island study areas (Fig. 1) in summer 1997. Although prey availability may vary seasonally, we assumed that relative differences between study areas in summer would also reflect relative winter prey abundance because these invertebrates, as a rule, do not experience multiple generations within the year. To sample intertidal blue mussels Mytilus trossulus, we removed all mussels from within $10500 \mathrm{~cm}^{2}$ quadrats placed in the mussel zone of each site. Ash-free dry mass of each mussel 5 to $25 \mathrm{~mm}$ in length (the size range appropriate for consumption by ducks) was estimated based on predictive equations of biomass by length. Samples of other invertebrate prey (limpets, chitons, lacunid snails, littorine snails, other snails, amphipods and other crustaceans) were obtained at 6 intertidal and shallow subtidal locations within each prey sampling site. All epifauna were removed from a $0.25 \mathrm{~m}^{2}$ quadrat at each location. Ashfree dry weights of each prey item $<25 \mathrm{~mm}$ in length were determined using a muffle furnace. We compared 2 metrics of food availability between areas: food biomass density and total food biomass relative to harlequin duck abundance. Food biomass density was defined as average $g$ ash-free dry weight per $100 \mathrm{~m}^{2}$; we used $t$-tests to compare food biomass densities between areas. Total food biomass was estimated as density expanded to the area of potential foraging for each sampling site (a $200 \mathrm{~m}$ shoreline segment by the width of the intertidal zone). Average total food biomass across sampling sites was divided by average number of harlequin ducks per sampling site to generate the metric

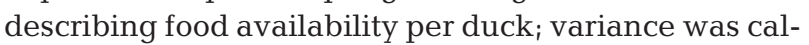
culated for a ratio of 2 independent estimates (Seber 1973) and 2-tailed $Z$-scores were calculated to compare areas (Snedecor \& Cochran 1980). Biomass density and total food biomass comparisons were conducted for all food items combined and also with mussels excluded because mussel abundance was much higher than for other prey species, yet they constitute a relatively minor part of the diet. Higher food densities or more food per duck on oiled than unoiled areas would imply that food limitation does not constrain recovery. Similar densities or quantities of food per duck between areas would be somewhat equivocal. Higher food densities or more food per duck on unoiled areas than oiled would be consistent with food limitation to population recovery. In 1997, food biomass densities were similar between oiled Knight Island and unoiled Montague Island study areas (Esler et al. 2000a; Table 3). Also, on a per duck basis, total food biomass was similar between areas (Table 3). These data were highly variable, but generally consistent with a hypothesis of no food limitation to population recovery.

Food variables were also incorporated into habitat association models to determine whether harlequin 
duck densities were related to food biomass density or total food biomass (Esler et al. 2000a). Strong relationships between food density or abundance and duck densities would suggest that harlequin ducks may be susceptible to food limitation. Biomass density and total biomass of harlequin duck prey items did not explain additional variation in harlequin duck densities beyond effects of habitat and history of oil contamination (Esler et al. 2000a). However, when data for mussels were excluded, prey biomass density was slightly, positively related to harlequin duck density, although this was strongly influenced by a single observation, without which there was no relationship.

Finally, body mass (see above) should provide strong evidence for the potential for food limitation. We would expect body mass to be lower in oiled than unoiled areas if food were limiting recovery, although other factors also could cause body mass differences. Body mass (see above) did not differ dramatically between areas, suggesting that food limitation was not occurring.

\section{DISCUSSION}

\section{Injury and recovery status}

Our harlequin duck studies, and this review, were focused on effects of the EVOS at the level of the population. We agree with Underwood \& Peterson (1988), who described population-level evaluation as a link between the physiological mechanisms that affect individuals, subsequent effects on demography, and potential impacts on community and ecosystem processes. In this light, we summarize the findings of our review in terms of level of biological organization (Table 4) and discuss the implications for population injury and recovery.

The evidence from postspill harlequin duck research and monitoring supports the conclusions that (1) harlequin duck populations were reduced by the EVOS; (2) these populations had not fully recovered by 1998; and (3) continued, direct effects of the EVOS were still occurring for as long as 9 yr after the EVOS. Key data (Table 4) leading to these conclusions include evidence of acute harlequin duck mortality immediately following the spill (J. Piatt pers. comm.), continued exposure of harlequin ducks to oil through at least 1998 (Trust et al. 2000), differing fall population trends in oiled and unoiled areas from 1995-1997 (Rosenberg \& Petrula 1998), lower densities than expected on oiled areas during winters 1995-1996 and 1996-1997 (Esler et al. 2000a) and differences in adult female survival between oiled and unoiled areas during winters 19951996 through 1997-1998 (Esler et al. 2000b). These results are internally consistent, i.e. predictions from each study are confirmed in the others. Differences in adult female survival offer a likely mechanism for divergence in population trends between areas. Under conditions of low survival, population declines and high site fidelity, densities would be expected to be depressed in the oiled area, which we observed. The adult female survival analysis is particularly important for our interpretation; it demonstrates continued EVOS effects and describes the demographic mechanism that would lead to persistent population declines. Missing from these studies (Table 4) is a clear link between exposure and subsequent variation in survival; changes in physiology and metabolism presumably result from oil exposure (Leighton 1993, Jenssen 1994), although such responses are difficult to detect under field conditions. Laboratory experiments addressing these mechanisms would be exceedingly useful. The negative relationship between CYP1A induction and body mass suggests that such a mechanism may have been operating. Also, there are no data that address changes in community structure or ecosystem processes that may have resulted from lack of recovery of harlequin duck populations (Table 4); hence, it is impossible to evaluate indirect effects on other system components or processes.

Not all studies of harlequin duck population status and trends give consistent conclusions. US Fish and Wildlife marine bird survey data (Lance et al. 1999) suggest increasing numbers on oiled areas during winter through 1998, consistent with ongoing population

Table 3. Biomass density and total biomass of harlequin duck prey (amphipods, chitons, limpets, other snails and mussels $<25 \mathrm{~mm}$ ) at oiled and unoiled study areas within Prince William Sound, Alaska, 1997 (mean \pm SE)

\begin{tabular}{|lccc|}
\hline Parameter & $\begin{array}{c}\text { Montague Island } \\
\text { (unoiled) }\end{array}$ & $\begin{array}{c}\text { Knight Island } \\
\text { (oiled) }\end{array}$ & $p$ \\
\hline Biomass density (g AFDW ${ }^{\mathrm{a}}$ per 100 $\mathrm{m}^{2}$ ) & $2030.8( \pm 555.2)$ & $1964.1( \pm 638.9)$ & $0.94(t=0.08)$ \\
Total biomass (kg AFDW per duck) & $51.8( \pm 16.4)$ & $100.5( \pm 52.0)$ & $0.81(Z=0.24)$ \\
Biomass density without mussels (g AFDW per 100 $\left.\mathrm{m}^{2}\right)$ & $45.9( \pm 10.1)$ & $42.8( \pm 7.3)$ & $0.80(t=0.251)$ \\
Total biomass without mussels (kg AFDW per duck) & $3.9( \pm 1.2)$ & $3.2( \pm 1.5)$ & $0.94(Z=0.08)$ \\
aAsh free dry weight & & & \\
\hline
\end{tabular}


Table 4. Histrionicus histrionicus. Summary of findings from studies relevant for understanding harlequin duck population injury, status of population recovery and constraints on full recovery in Prince William Sound (PWS), Alaska, following the 1989 ‘Exxon Valdez' oil spill. Findings are arranged by level of biological organization and interpreted in terms of population processes

\begin{tabular}{|c|c|c|}
\hline Parameter & Findings & Source \\
\hline \multicolumn{3}{|l|}{ Individual } \\
\hline \multirow[t]{2}{*}{ Oil exposure } & Hydrocarbon metabolites in 1989 to 1990 & Patten et al. (2000) \\
\hline & Elevated CYP1A through 1998 on oiled areas & Trust et al. (2000) \\
\hline \multirow[t]{2}{*}{ Mass variation } & No consistent, strong population-level differences between areas & This document \\
\hline & $\begin{array}{l}\text { Negative relationship between mass and CYP1A induction in } \\
\text { late winter }\end{array}$ & This document \\
\hline \multicolumn{3}{|l|}{ Population demography } \\
\hline Initial mortalities & Approximately 1000 & $\begin{array}{l}\text { Piatt et al. (1990), } \\
\text { J. Piatt pers. comm. }\end{array}$ \\
\hline Adult female survival & Lower in oiled areas than unoiled areas & Esler et al. (2000b) \\
\hline Dispersal & Generally low in the species; molt site fidelity high in PWS & $\begin{array}{l}\text { Breault \& Savard 1999), } \\
\text { Robertson et al. (1999), } \\
\text { Cooke et al. (2000), } \\
\text { This document }\end{array}$ \\
\hline Reproduction/recruitment & Similar age ratios between areas; most breeding outside PWS & Rosenberg \& Petrula (1998) \\
\hline \multicolumn{3}{|l|}{ Population status } \\
\hline \multirow[t]{8}{*}{ Abundance/densities } & Lower densities on oiled areas during summers 1990 and 1991 & Irons et al. (2000) \\
\hline & Summer abundance 1989 to 1991 unchanged from pre-spill & Murphy et al. (1997) \\
\hline & $\begin{array}{l}\text { Stable summer and increasing winter densities in oiled areas } \\
1989 \text { to } 1998\end{array}$ & Lance et al. (2001) \\
\hline & Similar summer and winter trends in density 1989 to 1998 & Lance et al. (2001) \\
\hline & $\begin{array}{l}\text { Numerical declines during fall of } 1995 \text { to } 1997 \text { on oiled areas, } \\
\text { stable on unoiled }\end{array}$ & Rosenberg \& Petrula (1998) \\
\hline & Densities lower than expected on oiled areas, winter 1995 to 1997 & Esler et al. (2000a) \\
\hline & Densities related to oiling intensity 1989 to 1990, not 1991 & Day et al. (1997) \\
\hline & $\begin{array}{l}\text { Population model predicts declines on oiled areas, stable } \\
\text { on unoiled }\end{array}$ & Esler et al. (2000b) \\
\hline
\end{tabular}

recovery, although these surveys are statistically less powerful than those of the Alaska Department of Fish and Game (Rosenberg \& Petrula 1998) that described declining numbers on oiled areas. However, lack of differences in population trends between oiled and unoiled areas based on the US Fish and Wildlife Service surveys was interpreted as evidence of lack of recovery (Lance et al. 1999).

Wiens et al. (1996) reported rapid recovery of bird communities following the EVOS based on measures of species richness and diversity. These parameters are derived from measures of presence or absence of a species within the study areas. For understanding recovery of populations, occurrence in oiled habitats is an incomplete measure. For example, occurrence of harlequin ducks in oiled areas most likely reflects high site fidelity (Cooke et al. 2000) despite deleterious changes in habitat quality (Hilden 1965, Cooch et al. 1993) and declines in abundance. Occurrence in an area does not indicate a recovered population; populations could, in fact, be declining or a demographic 'sink' (Pulliam 1988). We agree with Paine et al. (1996) that measures of demographic processes are more powerful measures of injury and recovery than occurrence or abundance.

The habitat use studies of Day et al. (1997) indicated no EVOS effects on harlequin ducks during winter 1989 to 1991, in contrast to our findings of lower densities on oiled than unoiled areas (Esler et al. 2000a). This inconsistency may be a consequence of accumulating deleterious effects of the spill that extended beyond the study period of Day et al. (1997) and through at least our study period (Rosenberg \& Petrula 1998, Esler et al. 2000, Trust et al. 2000). Thus, density differences may have been larger and more detectable during our study in 1995 to 1997 than in 1989 to 1991. Also, we collected harlequin duck abundance and habitat data at the scale that harlequin ducks use wintering sites (i.e. 100s of $\mathrm{m}$ reflecting specific shoreline segments; Robertson et al. 1999, Cooke et al. 2000) rather than at the scale of entire bays used by Day et al. (1997); our approach presumably results in greater resolution and power to determine habitat affiliations and evaluate oil spill effects.

Because most harlequin ducks wintering in PWS breed elsewhere, results of pre- and postspill compar- 
isons of summer abundance by Murphy et al. (1997) have limited relevance for understanding dynamics of wintering populations, which we consider to be the core, demographically distinct population segments. Also, although Murphy et al. (1997) had high power for detecting a $50 \%$ postspill population decline, they did not report power for detecting smaller but biologically meaningful reductions (e.g. 10\%). In fact, they estimated 13.5, 6.4 and $11.9 \%$ reductions in harlequin duck numbers from prespill counts in 1989, 1990 and 1991, respectively, although these were not statistically significant. In contrast, Irons et al. (2000) detected significant negative effects for summer harlequin duck numbers in 1990 and 1991.

Body mass comparisons between oiled and unoiled areas did not indicate a mechanism for the observed lack of recovery. However, differences in body mass that are demographically relevant may be difficult to detect in wild populations, as significant mass declines may precede death by only a short period, particularly for animals naturally existing near a metabolic threshold (Goudie \& Ankney 1986). For example, body mass declines in captive, oiled mallards faced with other environmental stressors were detectable only within 2 wk of death (Holmes et al. 1979). Because dead animals are not available to sample, detecting populationlevel differences in body mass or condition of fieldcaptured ducks may be unlikely. The subtle but significant body mass decline with increasing CYP1A induction (Fig. 3) suggests that oil exposure may have been directly linked to changes in physiology of individuals.

Our conclusion of lack of full population recovery is supported by those data sets and approaches that are most powerful for assessing population status. Below we consider the potential mechanisms involved in lack of full population recovery.

\section{Intrinsic limitations on population growth rates}

Aggregations of harlequin ducks on wintering areas constitute demographically independent subpopulations from a population structure standpoint (Cooke et al. 2000). Winter site fidelity of harlequin ducks is high (Robertson 1997, Cooke et al. 2000) and pair formation occurs on the wintering areas (Gowans et al. 1997, Robertson et al. 1998). Because dispersal from wintering areas is limited, recovery of groups of birds in oiled areas must occur primarily through recruitment specific to that group (i.e. immigration from other areas does not contribute much to population change). Thus, factors that affect wintering aggregations are influencing subpopulations that are largely distinct demographic units, suggesting that harlequin ducks may be susceptible to constraints on population recovery due to intrinsic demographic limits to population growth rates.

However, demographic limitations on population growth rate cannot be invoked as the primary constraint to harlequin duck population recovery until lingering effects of the EVOS on survival are gone and the population in the oil spill zone can achieve positive growth. This was not the case through 1998, and the time frame for cessation of EVOS effects is unknown. However, once freed from other constraints to recovery (see below), recovery of populations will then be limited by the time necessary for intrinsic rates of increase to operate (Goudie et al. 1994). Because it is not clear what naturally regulates harlequin duck populations, nor the life stage where regulation or limitation occurs, it is difficult to predict recovery times of an injured winter harlequin duck subpopulation.

Results from genetic studies offer some good news for harlequin duck populations. Levels of dispersal, either historical or contemporary, have resulted in subpopulations within the oil spill zone that are not genetically distinct (Lanctot et al. 1999), i.e. the EVOS does not threaten a unique genetic resource. Also, these results may reflect low levels of juvenile dispersal that we were unable to detect; if this is the case, population recovery could be enhanced by some immigration.

\section{Continued exposure to oil}

A growing body of evidence indicates that PAHs from residual 'Exxon Valdez' oil were responsible for the observed CYP1A induction in oiled areas of PWS in sea ducks (Trust et al. 2000) and several other vertebrates (Marty et al. 1997, Woodin et al. 1997, Bodkin et al. 2002, Jewett et al. 2002). However, exposure does not necessarily indicate effects on individuals or populations (Underwood \& Peterson 1988). A critical question is whether oil exposure could cause physiological challenges that affect demographic properties which, in turn, have population-level consequences.

As described above, our data on adult female winter survival offer a likely explanation for continued injury to harlequin duck populations and, hence, lack of recovery. Although the survival differences between oiled and unoiled areas may appear small, harlequin duck population dynamics are particularly sensitive to changes in adult female survival (Goudie et al. 1994) because their life history is oriented toward long reproductive lifespans (Stearns 1992). Oil exposure (Leighton 1993, Jenssen 1994) could negatively affect harlequin duck health and subsequent survival. Continued oil exposure was the most likely mechanism constraining full population recovery through at least 1998. 
Most laboratory studies have shown that mallards Anas platyrhynchos do not suffer acute toxic effects of oil ingestion until very high doses. These studies have been used to infer that harlequin ducks also should not suffer deleterious physiological responses to residual 'Exxon Valdez' oil (Stubblefield et al. 1995, Boehm et al. 1996). However, these lab studies have been conducted under relatively benign conditions. Other lab studies have found that, with addition of other stressors such as cold temperatures, ducks that ingested oil suffered higher mortality than unoiled birds (Holmes et al. $1978,1979)$. This is a more appropriate analog for wild harlequin ducks, which exist under winter conditions with cold temperatures and limited foraging time and, hence, little flexibility for accommodating additive stresses (Goudie \& Ankney 1986).

The divergence of survival probabilities between oiled and unoiled areas during midwinter (Fig. 2) is consistent with the hypothesis that effects of oil are exacerbated by other stressors. Midwinter is presumably the most stressful period for harlequin ducks under natural conditions. Harlequin ducks feed by sight and during midwinter, when day length is shortest, they spend most of their day time foraging (Fischer 1998, Goudie \& Ankney 1986 ). PWS is one of the northernmost wintering areas for harlequin ducks (Robertson \& Goudie 1999); thus, daylight available for foraging is particularly limited. We therefore suggest that observed differences in winter survival and populations trends are linked to observed differences in contaminant exposure.

Oil exposure could occur through consumption of contaminated prey. In the marine environment, oil constituents can accumulate in bottom sediments and benthic, filter-feeding invertebrates (Fukuyama et al. 2000, Peterson 2001). Studies have documented hydrocarbons in harlequin duck prey from immediately postspill through 1995 (Boehm et al. 1995, Babcock et al. 1996, Short \& Babcock 1996, Wolfe et al. 1996, Patten et al. 2000). Also, contamination could occur through external contact with residual oil; surface sheening was observed in nearshore areas of PWS during the same period as our studies (Hayes \& Michel 1999), suggesting that this also could be a potential route of exposure. Metabolic consequences of external oiling are well documented (Jenssen 1994) and could result in increased mortality.

\section{Food limitation}

Available evidence suggests that food availability or quality is not limiting harlequin duck population recovery. Recovery of most duck prey, lack of a strong relationship between harlequin duck densities and food biomass density or abundance, similar food biomass density and abundance per duck between areas, and similar body masses between areas all support this conclusion.

Interpretation of food data is hampered by a lack of understanding of harlequin duck foraging strategies and the role of winter food abundance, density or quality in harlequin duck population regulation or limitation. Furthermore, we have no data to test causal, mechanistic relationships between winter food supply and carrying capacity. Thus, body mass data provide perhaps the strongest evidence against food limitation. Because harlequin duck body masses across seasons, sexes and ages did not show a consistent difference between oiled and unoiled areas, we conclude that food is unlikely to be a primary constraint to recovery of populations from oiled areas.

\section{CONCLUSIONS AND RECOMMENDATIONS}

We conclude that, as of 1998 , harlequin duck population recovery had not occurred, that continued oil exposure may be the primary mechanism constraining recovery and that lack of full recovery most likely will be further delayed after deleterious EVOS effects are gone due to intrinsic demographic limits to population growth rates. Our findings are concordant with studies of other nearshore vertebrates. For example, sea otters Enhydra lutris had elevated CYP1A (B. Ballachey unpubl. data), increased mortality in oiled areas through at least 1998 (Monson et al. 2000) and lack of return to prespill numbers in the most heavily oiled areas of PWS (Bodkin et al. 2002). Like harlequin ducks, food limitation did not appear to limit sea otter population recovery (Dean et al. 2000, 2002). However, sea otters and harlequin ducks both rely on benthic invertebrate prey that can accumulate hydrocarbons, which may explain the parallel findings.

Response of bird populations to the EVOS varied considerably. Populations of some bird species were apparently not reduced by the EVOS or recovered quickly (Bowman et al. 1995, 1997, Wiens et al. 1996). Black oystercatcher Haematopus bachmani breeding was depressed in 1989 to 1990 but nearly recovered by 1991 (Andres 1997). Direct effects of oil exposure and indirect effects of prey reduced by the EVOS were indicated as constraints to full recovery of injured pigeon guillemot Cepphus columba populations in PWS for at least a decade (Golet et al. 2002). Harlequin duck populations have an unfortunate combination of characteristics that make them particularly vulnerable to effects of the oil spill during nonbreeding parts of the annual cycle. These characteristics include a life history requiring high adult survival, occurrence in 
nearshore habitats that are strongly affected by oil spills and that may hold residual oil for years, adaptation to stable and predictable marine environments, high site fidelity and a diet of benthic invertebrates. The traits of harlequin ducks that make them (and other wildlife species sharing these traits) vulnerable to catastrophic oil spill effects also render them susceptible to effects of chronic, low-level pollution. Sensitive species like harlequin ducks, sea otters and pigeon guillemots appear to suffer deleterious effects of oil pollution at lower levels and for longer time periods than other species. The duration of the population level effects far exceeds the few years that have conventionally been assumed to represent recovery times for wildlife populations injured by oil pollution.

Acknowledgements. This work was funded primarily by the Exxon Valdez Oil Spill Trustee Council; the findings and conclusions are those of the authors and do not necessarily reflect the views or position of the Trustee Council. Administrative and financial support was also provided by the US Geological Survey and the US Fish and Wildlife Service. Duck data collection was assisted by: Brian Baetsle, Rick Ballas, Jeb Benson, Brad Benter, Katherine Brenner, Kathy Burek, Paul Cotter, Jennifer DeGroot, Bob Jarvis, Aaron Johnson, Jeffrey Mason, Danielle Mather, Dan Monson, Julie Morse, Dan Mulcahy, April Nielson, Jennifer Pratt, Dan Ruthrauff, Dorcas Schaeffer, Ted Spencer, Mike Stattleman and Michael Stoskopf. Field assistance for prey sampling included Christine Brodersen, Mary Drew, Daniel Fremgen, Patricia Harris, Max Hoberg, Dennis Jung, Erica Leder, Mandy Lindeberg, Bruce March, Anita Martin, Joshua Millstein, Jon Moreland, Jerry Phillips, Jeffrey Reglin, Michelle Sleeter, Justin Stekoll, Robert Thomas and Noele Weemes. Lab analysis of invertebrate prey was conducted by Mary Drew, Max Hoberg, Mandy Lindeberg, David Love, Bruce March, Joshua Millstein and Justin Stekoll. We thank the captains and crews of the vessels 'Auklet', 'Discovery', 'Julia Breeze', 'Kittiwake II' and 'Waters' for vessel support, and the staff of Fishing and Flying for aerial support and telemetry data collection. We thank Bob Jarvis, Bruce Menge, Cliff Pereira, Pete Peterson, Greg Robertson and Dan Roby for comments on earlier drafts of this manuscript.

\section{LITERATURE CITED}

Andres BA (1997) The Exxon Valdez oil spill disrupted the breeding of black oystercatchers. J Wildl Manag 61: 1322-1328

Babcock MM, Irvine GV, Harris PM, Cusick JA, Rice SD (1996) Persistence of oiling in mussel beds three and four years after the Exxon Valdez oil spill. Am Fish Soc Symp 18:286-297

Bergan JF, Smith LM (1993) Survival rates of female mallards wintering in the playa lakes region. J Wildl Manag 57: 570-577

Bodkin JL, Ballachey BE, Dean TA, Fukuyama AK and 5 others (2002) Sea otter population status and the process of recovery from the 1989 'Exxon Valdez' oil spill. Mar Ecol Prog Ser 241:237-253

Boehm PD, Page DS, Gilfillan ES, Stubblefield WA, Harner EJ (1995) Shoreline ecology program for Prince William
Sound, Alaska following the Exxon Valdez oil spill. Part 2. Chemistry and toxicology. In: Wells PG, Butler JN, Hughes JS (eds) Exxon Valdez oil spill: fate and effects in Alaskan waters. ASTM STP 1219. American Society for Testing Materials, Philadelphia, p 347-397

Boehm PD, Mankiewicz PJ, Hartung R, Neff JM, Page DS Gilfillan ES, O'Reilly JE, Parker KR (1996) Characterization of mussel beds with residual oil and the risk to foraging wildlife 4 years after the Exxon Valdez oil spill. Environ Toxicol Chem 15:1289-1303

Bowman TD, Schempf PF, Bernatowicz JA (1995) Bald eagle survival and population dynamics in Alaska after the Exxon Valdez oil spill. J Wildl Manag 59:317-324

Bowman TD, Schempf PF, Hodges JI (1997) Bald eagle population in Prince William Sound after the Exxon Valdez oil spill. J Wildl Manag 61:962-967

Breault AM, Savard JPL (1999) Philopatry of harlequin ducks moulting in southern British Columbia. In: Goudie RI, Petersen MR, Robertson GJ (eds) Behaviour and ecology of sea ducks. Canadian Wildlife Service Occasional Paper Series No 100, Ottawa, p 41-44

Burnham KP, Anderson DR (1998) Model selection and inference: a practical information theoretic approach. Springer-Verlag, New York

Cooch EG, Jefferies RL, Rockwell RF, Cooke F (1993) Environmental change and the cost of philopatry: an example in the lesser snow goose. Oecologia 93:128-138

Cooke F, Robertson GJ, Smith CM, Goudie RI, Boyd WS (2000) Survival, emigration and winter population structure of harlequin ducks. Condor 102:137-144

Conroy MJ, Costanzo GR, Stotts DB (1989) Winter survival of female American black ducks on the Atlantic coast. J Wildl Manag 53:99-109

Crowley DW (1994) Breeding habitat of harlequin ducks in Prince William Sound, Alaska. MSc thesis, Oregon State University, Corvallis

Crowley DW (1999) Productivity of harlequin ducks breeding in Prince William Sound, Alaska. In: Goudie RI, Petersen MR, Robertson GJ (eds) Behaviour and ecology of sea ducks. Canadian Wildlife Service Occasional Paper Series No. 100, Ottawa, p 14-20

Day RH, Murphy SM, Wiens JA, Hayward GD, Harner EJ, Smith LN (1997) Effects of the Exxon Valdez oil spill on habitat use by birds in Prince William Sound, Alaska. Ecol Appl 7:593-613

Dean TA, Bodkin JL, Jewett SC, Monson DH, Jung D (2000) Changes in sea urchins and kelp following a reduction in sea otter density as a result of the Exxon Valdez oil spill. Mar Ecol Prog Ser 199:281-291

Dean TA, Bodkin JL, Fukuyama AK, Jewett SC, Monson DH, O'Clair CE, VanBlaricom GR (2002) Food limitation and recovery of sea otters following the 'Exxon Valdez' oil spill. Mar Ecol Prog Ser 241:255-270

Esler D, Bowman TD, Dean TA, O'Clair CE, Jewett SC, McDonald LL (2000a) Correlates of harlequin duck densities during winter in Prince William Sound, Alaska. Condor 102:920-926

Esler D, Schmutz JA, Jarvis RL, Mulcahy DM (2000b) Winter survival of adult female harlequin ducks in relation to history of contamination by the Exxon Valdez oil spill. J Wildl Manag 64:839-847

Fischer JB (1998) Feeding behavior, body condition, and oil contamination of wintering harlequin ducks at Shemya Island, Alaska. MSc thesis, University of Massachusetts, Amherst

Fukuyama AK, Shigenaka G, Hoff RZ (2000) Effects of residual Exxon Valdez oil on intertidal Protothaca staminea: 
mortality, growth, and bioaccumulation of hydrocarbons in transplanted clams. Mar Poll Bull 40:1042-1050

Gaines WL, Fitzner RE (1987) Winter diet of the harlequin duck at Sequim Bay, Puget Sound, Washington. Northwest Sci 61:213-215

Galt JA, Lehr WJ, Payton DL (1991) Fate and transport of the Exxon Valdez oil spill. Environ Sci Tech 25:202-209

Golet $\mathrm{GH}$, Seiser PE, McGuire AD, Roby DD and 6 others (2002) Long-term direct and indirect effects of the 'Exxon Valdez' oil spill on pigeon guillemots in Prince William Sound, Alaska. Mar Ecol Prog Ser 241:287-304

Goudie RI, Ankney CD (1986) Body size, activity budgets, and diets of sea ducks wintering in Newfoundland. Ecology 67:1475-1482

Goudie RI, Ryan PC (1991) Diets and morphology of digestive organs of five species of sea ducks wintering in Newfoundland. J Yamashina Inst Ornithol 22:1-8

Goudie RI, Brault S, Conant B, Kondratyev AV, Petersen MR, Vermeer K (1994) The status of sea ducks in the North Pacific rim: toward their conservation and management. Trans N Am Wildl Nat Res Conf 59:27-49

Gowans B, Robertson GJ, Cooke F (1997) Behaviour and chronology of pair formation by harlequin ducks Histrionicus histrionicus. Wildfowl 48:135-146

Hayes MO, Michel J (1999) Factors determining the longterm persistence of Exxon Valdez oil in gravel beaches. Mar Poll Bull 38:92-101

Highsmith RC, Rucker TL, Stekoll MS, Saupe SM, Lindeberg MR, Jenne RN, Erickson WP (1996) Impact of the Exxon Valdez oil spill on intertidal biota. Am Fish Soc Symp 18: 212-237

Hilden O (1965) Habitat selection in birds - a review. Ann Zool Fenn 2:53-75

Holmes WN, Cronshaw J, Gorsline J (1978) Some effects of ingested petroleum on seawater-adapted ducks (Anas platyrhynchos). Environ Res 17:177-190

Holmes WN, Gorsline J, Cronshaw J (1979) Effects of mild cold stress on the survival of seawater-adapted mallard ducks (Anas platyrhynchos) maintained on food contaminated with petroleum. Environ Res 20:425-444

Hooten AJ, Highsmith RC (1996) Impacts on selected intertidal invertebrates in Herring Bay, Prince William Sound, after the Exxon Valdez oil spill. Am Fish Soc Symp 18: $249-270$

Houghton JP, Lees DC, Driskell WB, Lindstrom SC, Mearns AJ (1996) Recovery of Prince William Sound intertidal epibiota from Exxon Valdez oiling and shoreline treatments, 1989 through 1992. Am Fish Soc Symp 18:379-411

Irons DB, Kendall SJ, Erickson WP, McDonald LL, Lance BK (2000) Nine years after the Exxon Valdez oil spill: effects on marine bird populations in Prince William Sound, Alaska. Condor 102:723-737

Jenssen BM (1994) Review article: effects of oil pollution, chemically treated oil, and cleaning on the thermal balance of birds. Environ Poll 86:207-215

Jewett SC, Dean TA, Smith RO, Blanchard A (1999) The 'Exxon Valdez' oil spill: impacts and recovery in the softbottom benthic community in and adjacent to eelgrass beds. Mar Ecol Prog Ser 185:59-83

Jewett SC, Dean TA, Woodin BR, Hoberg MK, Stegeman JJ (2002) Exposure to hydrocarbons ten years after the Exxon Valdez oil spill: evidence from cytochrome P4501A expression and biliary FACs in nearshore demersal fishes. Mar Environ Res 54:21-48

Johnson ML, Gaines MS (1990) Evolution of dispersal: theoretical models and empirical tests using birds and mammals. Annu Rev Ecol Syst 21:448-480
King JR, Murphy ME (1985) Periods of nutritional stress in the annual cycle of endotherms: fact or fiction? Am Zool 25: 955-964

Lance BK, Irons DB, Kendall SJ, McDonald LL (1999) Marine bird and sea otter population abundance of Prince William Sound, Alaska: trends following the T/V Exxon Valdez oil spill, 1989-1998. Exxon Valdez oil spill restoration project annual report, No 98159. US Fish and Wildlife Service, Anchorage, Alaska

Lance BK, Irons DB, Kendall SJ, McDonald LL (2001) An evaluation of marine bird population trends following the Exxon Valdez oil spill, Prince William Sound, Alaska. Mar Poll Bull 42:298-309

Lanctot R, Goatcher B, Scribner K, Talbot S, Pierson B, Esler D, Zwiefelhofer D (1999) Harlequin duck recovery from the Exxon Valdez oil spill: a population genetics perspective. Auk 116:781-791

Leighton FA (1993) The toxicity of petroleum to birds. Environ Rev 1:92-103

Longcore JR, McAuley DG, Frazer C (1991) Survival of postfledging female American black ducks. J Wildl Manag 55: 573-580

Marty GD, Short JW, Dambach DM, Willits NH, Heintz RA, Rice SD, Stegeman JJ, Hinton DE (1997) Ascites, premature emergence, increased gonadal cell apoptosis, and cytochrome P4501A induction in pink salmon larvae continuously exposed to oil-contaminated gravel during development. Can J Zool 75:989-1007

Monson DH, Doak DF, Ballachey BE, Johnson A, Bodkin JL (2000) Long-term impacts of the Exxon Valdez oil spill on sea otters, assessed through age-dependent mortality patterns. Proc Natl Acad Sci USA 97:6562-6567

Murphy SM, Day RH, Wiens JA, Parker KR (1997) Effects of the Exxon Valdez oil spill on birds: comparisons of preand post-spill surveys in Prince William Sound, Alaska. Condor 99:299-313

Paine RT, Ruesink JL, Sun A, Soulanille EL, Wonham MJ, Harley CDG, Brumbaugh DR, Secord DL (1996) Trouble on oiled waters: lessons from the Exxon Valdez oil spill. Annu Rev Ecol Syst 27:197-235

Parrish JK, Boersma PD (1995) Muddy waters. Am Sci 83: $112-115$

Patten SM Jr, Crowe T, Gustin R, Twait P, Hastings C (2000) Assessment of injury to sea ducks from hydrocarbon uptake in Prince William Sound and the Kodiak Archipelago, Alaska, following the Exxon Valdez oil spill. Exxon Valdez oil spill natural resource damage assessment final report, Bird study No. 11. Alaska Department of Fish and Game, Division of Wildlife Conservation, Anchorage

Peterson CH (2001) The Exxon Valdez oil spill in Alaska: acute, indirect and chronic effects on the ecosystem. Adv Mar Biol 39:1-103

Piatt JF, Ford RG (1996) How many seabirds were killed by the Exxon Valdez oil spill? In: Rice SD, Spies RB, Wolfe DA, Wright BA (eds) Proc Exxon Valdez Oil Spill Symp. Am Fish Soc Symp 18:712-719

Piatt JF, Lensink CJ, Butler W, Kendziorek M, Nyeswander DR (1990) Immediate impact of the Exxon Valdez oil spill on marine birds. Auk 107:387-397

Pulliam HR (1988) Sources, sinks, and population regulation. Am Nat 132:652-661

Rattner BA, Hatfield JS, Melancon MJ, Custer TW, Tillitt DE (1994) Relation among cytochrome P450, AH-active PCB congeners and dioxin equivalents in pipping blackcrowned night-heron embryos. Environ Toxicol Chem 13: 1805-1812

Regehr HM, Smith CM, Arquilla B, Cooke F (2001) Post- 
fledging broods of migratory harlequin ducks accompany females to wintering areas. Condor 103:408-412

Robertson GJ (1997) Pair formation, mating system, and winter philopatry in harlequin ducks. PhD thesis, Simon Fraser University, Burnaby, BC

Robertson GJ, Cooke F (1999) Winter philopatry in migratory waterfowl. Auk 116:20-34

Robertson GJ, Goudie RI (1999) Harlequin duck: the birds of North America. The American Ornithologists Union, Washington, DC, and The Academy of Natural Sciences, Philadelphia

Robertson GJ, Cooke F, Goudie RI, Boyd WS (1998) The timing of pair formation in harlequin ducks. Condor 100: 551-555

Robertson GJ, Cooke F, Goudie RI, Boyd WS (1999) Withinyear fidelity of Harlequin Ducks to a moulting and wintering area. In: Goudie RI, Petersen MR, Robertson GJ (eds) Behaviour and ecology of sea ducks. Canadian Wildlife Service Occasional Paper Series, No 100, Ottawa, p 45-51

Robertson GJ, Cooke F, Goudie RI, Boyd WS (2000) Spacing patterns, mating systems, and winter philopatry in Harlequin Ducks. Auk 117:299-307

Rosenberg DH, Petrula MJ (1998) Status of harlequin ducks in Prince William Sound, Alaska after the Exxon Valdez oil spill, 1995-1997. Exxon Valdez oil spill restoration project final report, No 97427. Alaska Department of Fish and Game, Division of Wildlife Conservation, Anchorage

Schmutz JA, Rockwell RF, Petersen MR (1997) Relative effects of survival and reproduction on population dynamics of emperor geese. J Wildl Manag 61:191-201

Seber GAF (1973) The estimation of animal abundance. Griffen London

Short JW, Babcock MM (1996) Prespill and postspill concentrations of hydrocarbons in mussels and sediments in Prince William Sound. In: Rice SD, Spies RB, Wolfe DA, Wright BA (eds) Proc Exxon Valdez Oil Spill Symp. Am Fish Soc Symp 18:149-166

Slatkin M (1995) A measure of population subdivision based on microsatellite allele frequencies. Genetics 139:457-462

Snedecor GW, Cochran WG (1980) Statistical methods. Iowa State University Press, Ames

Editorial responsibility: Charles Peterson (Contributing Editor), Morehead City, North Carolina, USA
Stearns SC (1992) The evolution of life histories. Oxford University Press, New York

Stubblefield WA, Hancock GA, Ford WH, Ringer RK (1995) Acute and subchronic toxicity of naturally weathered Exxon Valdez crude oil in mallards and ferrets. Environ Tox Chem 14:1941-1950

Trust KA, Esler D, Woodin BR, Stegeman JJ (2000) Cytochrome P450 1A induction in sea ducks inhabiting nearshore areas of Prince William Sound, Alaska. Mar Poll Bull 40:397-403

Underwood AJ, Peterson CH (1988) Towards and ecological framework for investigating pollution. Mar Ecol Prog Ser 46:227-234

Vermeer K (1983) Diet of the harlequin duck in the Strait of Georgia, British Columbia. Murrelet 64:54-57

White GC, Burnham KP (1999) Program MARK - survival estimation from populations of marked animals. Bird Study 46 (Suppl):120-138

Wiens JA, Parker KR (1995) Analyzing the effects of accidental environmental impacts: approaches and assumptions. Ecol Appl 5:1069-1083

Wiens JA, Crist TO, Day RH, Murphy SM, Hayward GD (1996) Effects of the Exxon Valdez oil spill on marine bird communities in Prince William Sound, Alaska. Ecol Appl 6:828-841

Woodin BR, Smolowitz RM, Stegeman JJ (1997) Induction of cytochrome P4501A in the intertidal fish Anoplarchus purpurescens by Prudhoe Bay crude oil and environmental induction in fish from Prince William Sound. Environ Sci Tech 31:1198-1205

Wolfe DA, Hameedi MJ, Galt JA, Watabayashi G and 8 others (1994) The fate of the oil spilled from the Exxon Valdez. Environ Sci Tech 28:561-568

Wolfe DA, Krahn MM, Casillas E, Sol S, Thompson TA, Lunz J, Scott KJ (1996) Toxicity of intertidal and subtidal sediments contaminated by the Exxon Valdez oil spill. In: Rice SD, Spies RB, Wolfe DA, Wright BA (eds) Proc Exxon Valdez Oil Spill Symp. Am Fish Soc Symp 18: 121-139

Wright S (1931) Evolution in Mendelian populations. Genetics 16:111-123

Submitted: January 3, 2001; Accepted: April 26, 2002

Proofs received from author(s): September 10, 2002 